\title{
A Review on Newer Trends in the Use of Exogenous Fibrolytic Enzymes Use in the Ruminants
}

\author{
M.V.A.N. Suryanarayana* \\ Department of Livestock Farm Complex, College of Veterinary Science, Sri Venkateswara \\ Veterinary University, Tirupati-517501 (A P) India \\ *Corresponding author
}

\section{Ke y w o r ds \\ EFE, Forages, Rumen degradation, Cellulose, Crop residues}

\section{Article Info}

Accepted: 17 September 2020 Available Online: 10 October 2020

\section{A B S T R A C T}

Continuous efforts are being made to utilize the fibre feeds to the maximum extent in ruminants which form a staple feed in tropical countries. Though only about $65 \%$ of the fibre is effectively digested in the rumen, need to supplement certain exogenous fibrolytic enzymes (EFE) has become mandatory. The main principle with which EFE is added is to specifically target the increased bacterial multiplication of certain species which enhances rumen degradation of cellulose which constitutes the major part of the forages. Effectiveness of enzymes in animal nutrition depends on (i) type, (ii) source, (iii) level of supplemented enzymes, (iv)the type of diet fed, (v) animal health and (vi) animal productivity. Exogenous enzymes are classified into cellulolytic, amylolytic, proteolytic and others based on the type of substrate on which they act. The mode of application of EFE, incubation with the substrate is also crucial. Solubulized enzymes incubated with the substrate is more effective since the enzymes starts acting on the substrate forming a stable complex resistant to endogenous enzymes even before entering into the rumen. Supplementation of White-rot fungi in recent times improved the digestibility of the so called tough lignocellulosic bonded substrates fed to ruminants. Supplementation of EFE to silage can hydrolyze plant cell walls into fermentable substrates through enhanced homolactic fermentation and thus improves digestion. It was reported that EFE works in three ways - 1) improved feed conversion efficiency 2) release of entrapped nutrients from the cell wall portions of diets and 3) release of oligosaccharides which support beneficial microflora while suppressing pathogenic bacteria. It was known that the microbial mass in the rumen meets 80 to $90 \%$ energy and 60 to $70 \%$ protein needs in sheep for which efficient utilization of the fibrous crop residues is mandatory for which the use of EFE is required. However, animal responses to the enzyme supplementation are inconsistent and are possibly be attributed to four main factors: enzyme characteristics (differences in enzyme preparations, enzyme activity, units of activity added, $\mathrm{pH}$ and temperature effect on activity), forage (type, maturity), animal (species, age) and management (diet, mode of enzyme application, application rate, interaction time of enzymes applied to feed). It can be concluded that enzyme action is species specific, substrate specific, dosage specific, application mode specific, incubation period specific, source specific and hence long term trials are further suggested for not having consistent results and there is a great need to develop certain of the enzymes to more thermo stable and can resist the rumen $\mathrm{pH}$ and temperature. Since the any forage has three different digestible fractions viz- digestible, potentially digestible, and indigestible and the action of EFE which may be of any origin depends upon the extent of the digestibility of the potentially digestible fraction and this determines the magnitude of the response of the EFE towards forages. 


\section{Introduction}

Over the years, many methodologies have been brought to light in order to efficiently utilize the forages in ruminants by the use of different chemicals such as sodium hydroxide, hydrogen peroxide, anhydrous ammonia and urea. Owing a threat to the animals in the long use of these methods at farmers level, these methods were not popularized. As an alternate to these chemicals, Exogenous Fibrolytic Enzyme (EFE) supplementation was found to an effective way to improve the energy availability for ruminants. Use of EFE in the ruminant diet has been reported to improve the fiber digestibility and their use was popularized because of the positive effect on animal health and performance.

In tropical countries like India, ruminant production systems are based on crop residues and more of agricultural by-products rich in fibrous material which is important for salivation, rumen buffering and efficient production of rumen end products. However, to a maximum of $65 \%$ fibrous material in the feed stuffs are efficiently digested (Van Soest,1994) and the rest of the portion needs to be utilized to the full to follow economy. Forage digestibility has been improved by several biotechnological products like fibrolytic enzymes, ionophores, direct fed microbial products and certain fungi like Pleurotus which can degrade lignin. In recent times, addition of EFE to the feed stuff has shown promising results by hydrolysis of plant cell walls (Beauchemin et al., 2004).

Fibre is a major source of energy for ruminants (Avellaneda et al., 2009) because cellulose, one of the main components, is the most abundant biopolymer on Earth (Paloheimo et al., 2010). This fibre available to the animal, is of low quality and the energy present in the bound form in the fibre cell wall is unutilized to the animal, leading to a large excretion of nutrients and incomplete use of fractions of the cell wall in the rumen due to the complex links which limit the degradation of nutritional compounds. Here comes the use of EFE produced from fungal (largely Trichoderma longibrachiatum, Aspergillus niger, and A. oryzae) and bacterial (Bacillus spp., Penicillium funiculosum) sources with high cellulosic and hemicellulosic activity. EFE can be corporated in liquid or granular form with the total mixed ration, hay, silages, concentrates, supplements or premix, and increase the availability of nutrients in the cell wall.

Exogenous enzymes have been used to improve nutrient utilization in several species of livestock, particularly non-ruminants. In comparison, the use of exogenous enzymes in ruminant diets is restricted because it is hypothesized that the hydrolytic capacity of the rumen could not be enhanced by enzyme supplementation and concerns that such enzymes would be ineffective due to ruminal hydrolysis (Adesogan, 2005). Based on the work mainly in non-ruminant animals, efficacy of exogenous enzyme supplementation has been reported to work in three ways: 1) improved feed conversion efficiency, 2) release of nutrients trapped in the cell wall portions of diets and 3)release of oligosaccharides which support beneficial microflora while suppressing pathogenic bacteria (Paloheimo et al., 2010).

\section{Enzymes in cattle}

\section{Classes of exogenous enzymes}

Exogenous enzymes supplemented to animal diets include amylolytic enzymes, proteolytic enzymes, ß-glucanase, xylanase, Cellulase and $\beta$-mannanase. These enzymes are expected to increase the digestion and thus utilization of dietary starch, protein, $\beta$ - 
glucans, arabinoxylans, and mannan, respectively. Here we describe briefly amylolytic, proteolytic and fibrolytic enzymes supplemented to diets for ruminants.

\section{Amylolytic enzymes}

Amylolytic enzymes, also called as starch degrading enzymes are often fed with cereal grains such as corn and barley. These mainly act on glycosidic bonds and release more than 600 metabolizable glucose units (Pérez et al., 2009) and makes a very good energy source. Rojo et al., (2007) reported that the amylolytic enzyme a-amylase was more effective in increased starch digestion in ruminally cannulated beef steers. Alternatively, Tricarico et al., (2008) reported modified rumen fermentation products. Tricarico et al., (2005) found increased proportions of acetate and propionate in steers and lactating dairy cattle supplemented with exogenous alpha-amylase. However contradictory results were also reported by some workers which are attributed to several factors including enzyme dose, type of feed, host and management factors (Mendoza et al., 2014).

\section{Proteolytic enzymes}

These enzymes degrade the feed proteins in the rumen and release amino acids which are rightly utilized by the rumen microbes to synthesize the microbial protein. These enzymes also release the fibre cell bound protein .Though cell bound protein accounts to only $7-11 \%$ of the total cell wall content, its contribution to the overall protein digestibility is recognized by increased organic matter rumen fermentation.

\section{Exogenous fibrolytic enzymes}

Since most of the diet for ruminants includes carbohydrates, soluble carbohydrates are of no problem for hydrolysis but the issue is with non-starch polysaccharides in plant cell walls. Fibrolytic enzymes hydrolyze nonstarch polysaccharides in plant cell walls by targeting the main constituents including cellulose and hemicellulose. Hemicelluloses also have a substantial role in maintaining cell wall structure in plants and accounts for about one fourth of the total plant biomass (Scheller and Ulvskov, 2010). The most common types of fibrolytic enzymes that break down the structural carbohydrates in the rumen are xylanase, B-glucanase and B-mannanase for hemi-cellulose and cellulase for cellulose. Many authors say that instead of adding a single fibrolytic enzyme, mixture of enzymes in the form of enzyme cocktail improved (Salem et al., 2013) digestibility and rumen fermentation in beef steers. The effectiveness of supplementing ruminant diets with exogenous enzymes has been highly variable. This is likely due to variability in type of enzyme used, species, physiological status, rumen $\mathrm{pH}$, gastrointestinal conditions, enzyme dosage and nutrient composition of diets (Mendoza et al., 2014). Seo et al., (2016) reported increased average daily gain in growing beef heifers with dietary supplementation of B-mannanase. Tewoldebrhan et al., (2017) reported increased milk yield per unit of dry matter intake and milk protein yield per kilogram of crude protein intake with ß-mannanase supplementation in a corn silage and alfalfa hay-based diet fed to mid-lactating Holstein dairy cows.

Since Cellulose forms the major structural carbohydrate and also a major source of feed for ruminants, there is every need to discuss more about this. Cellulase is an enzyme produced chiefly by fungi, bacteria and protozoans and it can catalyze cellulolysis, the decomposition of cellulose and of some related polysaccharides. Cellulases break down the cellulose molecule into 
monosaccharides (simple sugars) such as beta-glucose or shorter polysaccharides and oligosaccharides. Most mammals have only very limited ability to digest dietary fibres like cellulose by themselves. In many herbivorous animals such as ruminants like cattle and sheep and hindgut fermenters like horses, cellulases are produced by symbiotic bacteria.

EFE mainly consists of Xylanase, betaglucanse and Cellulase and were evaluated for their potential to improve diet utilization and dairy cow performance and found the improvement in digestibility (Yang et al., 2000) but not others (Lewis et al., 1999). Supplementation has increased or tended to increase milk production in some studies (Kung et al., 2002), but not in others. These discrepancies are likely due to differences in enzyme activity and composition, stage of lactation of cows, physiological stage of the animals and method of enzyme addition.

The addition of EFE can be in different forms Viz- solid and liquid forms. The EFE can also be given by direct infusion into the rumen or abomasum but the results were not prominent (Hristov et al., 1998) as compared to the EFE addition by solid or liquid forms to the dietary forage (Lewis et al., 1999) or concentrate (Rode et al., 1999) indicating a close relation between the fibre substrate and the enzyme for fiber hydrolysis (Beauchemin et al., 1999). Addition of EFE to forages are said to be more effective than adding to the concentrates. Exogenous enzymes should also be more effective when applied to highmoisture feeds such as silages than to dry feeds because of the importance of water for enzymatic cell wall hydrolysis (Beauchemin et al., 1999).

Yang et al., (2000) has reported that EFE application to concentrates were more effective than for TMR. It was also reported that the efficacy of EFE is positively correlated to the composition of the diet (Bowman et al., 2002). Supplementation with (EFE) is thought to enhance ruminal fermentation and to increase the degradability of forage cell walls, potentially reducing feed costs and sustaining the productive performance of ruminants; however, the underlying interactions are unknown and the effects of using EFE are highly variable.

Within the rumen, EFE hydrolyse cell wall components and produce substrates that favour the multiplication of certain specific microbes even with low-forage diets (Bedford and Cowieson 2012). In the ruminal environment, EFE can affect bacterial attachment and colonization and microbial populations (Colombatto and Mould et al., 2003; Wang et al., 2012), affecting in vitro (Srinivas et al., 2008), in situ (Tirado-Estrada et al., 2015) and in vivo NDF digestibility.

There are reports saying contradictory results on the growth performance on adding EFE. The reasons are attributed to many factors like method of application of EFE viz-in liquid form or in solid form, dose of enzyme, contact time of the enzyme with the substrate, type of substrate, presence of strong lingocellulosic bonds etc. The problem appears when fibre high in ligno-cellulose diets are fed. However, when using high lingo cellulolytic ingredients (agricultural by products), the results have been variable and inconsistent in terms of fibre digestibility (Gallardo et al., 2010) because the potential of exogenous enzymes depends mainly on the dose and type of substrate. So it is possible that lower quality forages require higher doses of exogenous fibrolytic enzymes in order to show benefits such as those observed with higher quality forage (Eun et al., 2008 a).

Supplementation of enzymes in solubilized form recorded higher digestibility coefficients for $\mathrm{CF}$, NDF, ADF, cellulose and 
hemicellulose which was due to the pretreatment of dry feeds with enzyme in liquid form that forms stable feed-enzyme complex (Pradeep Kumar Reddy et al., 2018) before entering the rumen where the action of the enzyme starts on the substrate. Suryanarayana and Ramana (2015) conducted a trial on 100 ram lambs by applying the EFE in both solubulized and dry forms and concluded that the FCR was lower $(\mathrm{P}<0.05)$ by $21 \%, 26 \%$ and $13 \%$ for the solubilized enzyme supplemented group as compared to control and other groups. Improvement in $\mathrm{ADF}$ and NDF $(\mathrm{P}<0.001)$ digestibility was noticed $(\mathrm{Mc}$ Allister et al., 2000) in lambs supplemented with Cellulase and Xylanase for forage diets containing barley straw, wheat straw and alfalfa hay. Similar trend $(\mathrm{P}<0.05)$ in digestibility of $\mathrm{DM}, \mathrm{OM}, \mathrm{CF}, \mathrm{NDF}$ and $\mathrm{ADF}$ was noticed for lambs fed with TMR supplemented with Cellulase (Titi and Tabbaa, 2004). While applying the enzymes care needs to be taken to have uniform distribution of enzymes since these are added at relatively low levels. Enzyme application at ensiling is a classical example because uniform distribution throughout the forage can be ensured when enzymes are applied using properly calibrated sprayers.

Supplementation of EFE while ensiling can hydrolyze plant cell walls into fermentable substrates that improve digestibility through enhanced homolactic fermentation. Reporters say that addition of fibrolytic enzymes at ensiling has improved the fermentation and nutritive value of corn silage and Bermuda grass silage.

\section{Enzymes in sheep}

In a developing country like India, where around 18 per cent of the gross domestic product (GDP) is obtained from agriculture, the livestock sector plays an important role in the national economy ( $4.36 \%$ of the GDP).
Among the livestock, sheep as a small ruminant has a great potential to provide gainful employment and nutrition round the year to the small, marginal and landless farmers besides providing surplus marketable products (Economic survey of India, 200809).

In sheep, scarcity of green fodder and high cost of conventional feed ingredients have made the researchers to improve the feeding value of poor quality crop residues. In India, due to continuous depletion of grazing lands and scarcity of feeds and fodder, farmers are forced to feed the crop residues which are poor in nutritive value owing to their low energy, low nitrogen, low minerals, high fibre and high acid insoluble ash content that are available in large quantities after harvesting the crops.

The efficiency of utilization of low quality crop residues and roughages by sheep for growth purpose could be altered by a higher rate and extent of digestion in rumen and better availability of microbial nutrients in the feed to support an efficient microbial growth, which could meet 80 to $90 \%$ energy and 60 to $70 \%$ protein needs in sheep.

To improve the consistency of the results, it is important to know the interaction within the ruminal ecosystem, the cell walls of plants and the type of EFE (Meale et al., 2014).

Many researchers reported positive effects of using EFE as supplements for ruminants on dry matter and neutral detergent fibre in vivo digestibility (DMD and NDFD) (Arriola et al., 2011) total volatile fatty acids, propionic acid proportion, acetate: propionate ratio, dry matter intake (DMI) (Chung et al., 2012), milk production (Kholif and Aziz 2014) and average daily gain (ADG) (Tirado-Estrada $e t$ al., 2011). 
Factors on which the enzymes activity depends

The activity of the EFE on a feed depends on various factors like source of supply of the enzymes (bacterial/fungal origin), type of substrate, mode of application of EFE (solid/liquid), type and stability of the enzyme, $\mathrm{pH}$, temperature and the other conditions in the rumen, dose of enzymes, presence of certain enzyme inhibitors in the gut, stability conditions of EFE and the type of livestock species (ruminants/nonruminants). Marquez et al., (2009) has stated that the activities of Xylanase and Cellullase produced from Trametes species is $5 \& 7$ times and $10 \& 8$ more active as compared to these produced from Asperigillus and Pleurotus species, respectively.

In conclusion, the use of EFE can be promoted in ruminant production systems by developing these at cheaper rates. In future it becomes inevitable to use these enzymes in TMR. Animal responses were inconsistent to the addition of enzymes and the reasons are multifactorial and can possibly be attributed to four main factors: enzyme characteristics (differences in enzyme preparations, enzyme activity, units of activity added, $\mathrm{pH}$ and temperature effect on activity), forage (type, maturity), animal (species, age) and management (diet, mode of enzyme application, application rate, interaction time of enzymes applied to feed). A thorough knowledge on the potentially degradable fibre fractions and the digestion kinetics need to be known. Addition of EFE to the fibre diets may not be a tough task but this small intervention leads to the efficient utilization of nutrients and a healthy eco balance of bacteria in the rumen. However newer fibrolytic enzymes need to be prepared that can be thermo stable and can resist a p $\mathrm{H}$ of 6 to 6.8 and a temperature of $39^{\circ} \mathrm{C}$ simulating the rumen conditions. While supplementing these enzymes, factors like mode of application, substrate nature, dosage, period of incubation, source of supply etc have to be taken into consideration.

\section{References}

Adesogan, A. T., 2005. Improving forage quality and animal performance with fibrolytic enzymes. In Proc. 16th Annual Florida Ruminant Nutrition Symposium, Gainesville, Florida. pp 91-109.

Arriola, K.G., Kim, S.C., Staples, C.R., Adesogan, A. T. 2011. Effect of fibrolytic enzyme application to low- and highconcentrate diets on the performance of lactating dairy cattle J. Dairy Sci., 94, 832-841.

Avellaneda, J. H., Pinos-Rodríguez, J. M., González, S. S. 2009. Effects of exogenous Fibrolytic enzymes on ruminal fermentation and digestion of Guinea grass hay Anim. Feed Science and Technol vol. 149, no. 1-2, pp. 70-77.

Beauchemin, K. A., Colombatto, D., Morgavi, D.P, Yang, W.Z., Rode, L.M., 2004. Mode of action of exogenous cell wall degrading enzymes for ruminants Can $\mathrm{J}$ Anim Sci. 84, 13-22.

Beauchemin, K. A., Rode, L. M. and Karren, D. 1999. Use of feed enzymes in feedlot finishing diets. Can J Anim Sci 79(2), 243-246.

Bedford, M. R., Cowieson, A. .J 2012 . Exogenous enzymes and their effects on intestinal microbiology Anim. Feed Science and Technol 173, 76-85.

Bowman, G. R., Beauchemin, K.A., Shelford, J. A., 2002. In vitro degradation of fresh substrates treated with exogenous fibrolytic enzymes. Can J Anim Sci. 82, 611-615

Chung, Y.H., Zhou, M., Holtshausen, L., Alexander, T.W., McAllister, T.A., Guan, L. L, Oba, M., Beauchemin, K A., 2012. A fibrolytic enzyme additive for lactating Holstein cow diets: ruminal fermentation, rumen microbial populations, and enteric 
methane emissions. J Dairy Sci 95, 14191427

Colombatto, D., Mould, F.L., Bhat, M.K., Morgavi, D.P., Beauchemin, K.A., Owen, E. 2003. Influence of fibrolytic enzymes on the hydrolysis and fermentation of pure cellulose and xylan by mixed ruminal microorganisms in vitro. J Anim Sci 81, 1040-1050

Dean, D. B., Adesogan, A. T., Krueger, N. A., Littell, R. C. 2008. Effects of treatment with ammonia or fibrolytic enzymes on chemical composition and ruminal degradability of hays produced from tropical grasses. Anim. Feed Sci and Technol. 145, 68-83

Economic survey of India, 2008-2009

Eun, J. S. and Beauchemin, K. A., 2008a. Assessment of the potential of feed enzyme additives to enhance utilization of corn silage fibre by ruminants. Can J Anim Sci. 88, 97-106

Gallardo, I., Bárcena, R., PinosRodríguez, J. M., Cobos, M., Carreón, L., Ortega, M. E. 2010. Influence of exogenous fibrolytic enzymes on in vitro and in sacco degradation of forages for ruminants. Italian J Anim Sci. 98, 34-38

Hristov, A. N., McAllister, T. A. and Cheng, K. J. 1998. Stability of exogenous polysaccharide-degrading enzymes in the rumen. Anim. Feed Sci and Technol. 76, 161-168

Kholif ,A. M., Aziz, H. A. 2014. Influence of feeding cellulolytic enzymes on performance, digestibility and ruminal fermentation in goats. Anim. Feed Sci and Technol. 14(1), 121-136

Kung, L., Cohen, M. A., Rode, L. M. and Treacher, R. J. 2002. The effect of fibrolytic enzymes sprayed onto forages and fed in a total mixed ratio to lactating dairy cows. J Dairy Sci 85(9), 2396-2402

Lewis, G. E., Sanchez, W. K., Hunt, C. W., Guy, M. A., Pritchard, G. T., Swanson, B. I. and Treacher, R. J. 1999. Effect of direct-fed fibrolytic enzymes on the lactational performance of dairy cows. $\mathbf{J}$ Dairy Sci 82(3), 611-617.
Marquez, A., Mendoza, G., PinosRodríguez, J.M., Zavaleta, H., González, S., Buntinx S., Loera, O., Meneses, M.2009. Effect of fibrolytic enzymes and incubation $\mathrm{pH}$ on in vitro degradation of NDF extracts of alfalfa and orchardgrass. Italian $\mathrm{J}$ Anim Sci. 8,221-230

McAllister, T. A., Hristov, A. N., Beauchemin, K. A., Rode, L. M. and Cheng, K. J. 2001. Enzymes in ruminant diets. in Enzymes in Farm Animal Nutrition M. R. Bedford and G. G. Partridge, eds. CAB Publishing, Oxon. pp 273-297.

Mendoza, G. D., Loera-Corral, O., Plata-Pérez, F. X., Hernández-García, P. A. and Ramírez-Mella, M. 2014. Considerations on the use of exogenous fibrolytic enzymes to improve forage utilization. The Scientific World Journal

Meale, S. J., Beauchemin, K. A., Hristov, A. N., Chaves, A.V., McAllister, T. A.2014. Invited review: opportunities and challenges in using exogenous enzymes to improve ruminant production $\mathrm{J}$ Anim Sci. 92(2), 427-442

Paloheimo, M., Piironen, J. and Vehmaanpera, J. 2010. Xylanases and cellulases as feed additives - in Enzymes in Farm Animal Nutrition, M. R. Bedford and G. G. Partridge, Eds., pp. 12-53, CAB International, London, UK, 2nd edition

Pérez, S., Baldwin, P. M. and Gallant, D. J. 2009. Chapter 5 - Structural Features of Starch Granules I. Pages 149-192 (Third Edition). Academic Press, San Diego.

Rojo, R., Mendoza, G. D., Plata, F. X. , Lara, A. and Bárcena, R.2007. Comparison of Method of Application on the Effect of amylolytic enzymes on in vitro ruminal starch digestion. J Appl Anim Res. 32, 81-84.

Rode, L. M ., Yang, W.Z ., Beauchemin, K. A.1999. Fibrolytic enzyme supplements for dairy cows in early lactation. J Dairy Sci. 82, 2121-2126

Pradeep Kumar Reddy, Y. 2018. Effect of feeding fibrolytic enzyme mixture in dry and solubilized forms on the performance of ram lambs fed jowar stover based total 
mixed ration Post graduate thesis submitted to SVVU

Scheller, H. V. and Ulvskov, P. 2010. Hemicelluloses. Ann. Rev. Plant Biology 61, 263-289.

Salem, A. Z., Gado, M.H.M., Colombatto,D. and M.M.Y. Elghandour.2013. Effects of exogenous enzymes on nutrient digestibility, ruminal fermentation and growth performance in beef steers. Livestock Science 154, 69-73.

Seo, J. J., Park, J. Lee, J.H., Lee, J. J., Lee Kam, D. K., and Seo, S. 2016. Enhancement of daily gain and feed efficiency of growing heifers by dietary supplementation of Bmannanase in Hanwoo (Bos taurus coreanae). Livestock Science 188, 21-24.

Srinivas, B., Chaturvedi, O.H., Malik, R., Asgar, M. 2008. Effect of enzyme to substrate ratio of exogenous fibrolytic and protease enzymes on in vitro gas production kinetics Indian J Small Ruminants 14 (2), 181-190

Suryanarayana, M.V.A.N. and Ramana, J.V. 2015. Effect of feeding enzyme mixture with fibrolytic activity in dry and solubilized forms on the performance of lambs. J Vet Sci and Technol. 6 (6), 53.

Tewoldebrhan,T. A., Appuhamy, J.A.D.R.N., Lee, J., Niu, M., Seo, S., Jeong, S., and Kebreab, E. 2017. Exogenous Bmannanase improves feed conversion efficiency and reduces somatic cell count in dairy cattle J Dairy Sci. 100, 244-252.

Tricarico,J.M., Johnston, J. D. and Dawson, K. A. 2008. Dietary supplementation of ruminant diets with an Aspergillus oryzae a-amylase. Anim. Feed Sci and Technol. 145,136-150.

Tricarico, J.M., Johnston, J. D. and Dawson, K. A., Hanson, K.C. and McLeod, K R.2005. The effects of an Aspergillus oryzae extract containing alpha-amylase activity on ruminal fermentation and milk production in lactating Holstein cows. J Anim Sci 81, 365-374

Tirado-Estrada, G., Mendoza-Martínez, G. D., Pinos-Rodríguez, J. M., Quezada-Tristán, T. and Guevara-Lara, F. 2011. Effects of two fibrolytic enzyme mixtures on growth performance, digestion and ruminal fermentation in lambs fed corn stover based diets J Appl Anim Res. 39(2), 158160.

Titi, H. H. and Tabbaa, M. J. 2004. Efficacy of exogenous cellulase on digestibility in lambs and growth of dairy calves. Liv Prod Sci. 87, 207-214.

Van Soest, P. J. 1994. Nutritional Ecology of the ruminant, Second Ed. Cornell University Press, Ithaca, NY.

Wang, Y., Ramirez-Bribiesca, J.E., Yanke, L. J., Tsang, A. and McAllister, T.A. 2012. Effect of exogenous fibrolytic enzyme application on the microbial attachment and digestion of barley straw in vitro. Asian-Austral J Anim Sci 25(1), 66.

Yang, W. Z., Beauchemin, K. A. and Rode, L. M. 2000. A Comparison of Methods of Adding Fibrolytic Enzymes to Lactating Cow Diets1. J Dairy Sci. 83 (11),25122520.

\section{How to cite this article:}

Suryanarayana, M.V.A.N. 2020. A Review on Newer Trends in the Use of Exogenous Fibrolytic Enzymes Use in the Ruminants. Int.J.Curr.Microbiol.App.Sci. 9(10): 2242-2249. doi: https://doi.org/10.20546/ijcmas.2020.910.271 